\title{
Airway management in a pediatric patient with post-burn neck contracture using i-gel
}

\author{
Yanık sonrası boyun kontraktürlü çocuk hastada i-gel kullanarak hava yolu yönetimi
}

Taner Çiftci ${ }^{1}$, Hayrettin Daşkaya ${ }^{2}$, Caferi Tayyar Selçuk ${ }^{3}$, Mustafa Durğun ${ }^{3}$, Fikret Salık ${ }^{1}$, Mehmet Beşir Yıldırım

\begin{abstract}
l-gel is a supraglottic airway device that has been used for emergency airway management. In this report, we present a case in which airway management is facilitated using l-gel. Scar revision was planned in a 12-year-old male patient with limited ability to extend the neck and restricted oral opening because of post-burn contracture. The patient was ventilated successfully achieved using the supraglottic l-gel method. This new airway device may appropriate in cases with asymmetric airways in which airway management is difficult. J Clin Exp Invest 2014; 5 (2): 301-303
\end{abstract}

Key words: Post-burn neck contracture, airway management, l-gel

\section{INTRODUCTION}

Post-burn scar formation, particularly in the face, head, neck, and sternal regions, could make airway management difficult in pediatric patients. Contracture may have a rotation effect on the tracheolaryngeal cartilage which could make conventional methods of intubation ineffective. During preoperative evaluation, on these patients, predicting possible problems with intubation and providing emergency equipment for difficult airway management is essential. I-gel is a new device that allows safe airway access. Its flexible and well-fitting structure prohibits air leakage and facilitates intubation in cases where airway access is difficult.

We report the case of a pediatric burn patient presenting with difficult airway management that was alleviated without discomfort through use of Igel.

\section{ÖZET}

Boyunda var olan yanık sonrası gelişmiş kontraktürler, hava yolu yönetiminde ciddi problemlere yol açabilmektedir. Bu olguda alev yanığı sonrasında ciddi boyun kontraktürüne bağlı gelişen ekstansiyon kısıtlıığı ve kısıtlı ağız açıklığı olan 12 yaşındaki erkek çocuk hastadaki zor hava yolu yönetimi sunulmuştur. Hastada no:2.5 i-gel supraglottic airway ile ventilasyon sağlandı. Bu yeni hava yolu aracı hava yolu yönetimi zor olan asimetrik hava yolu olan olgularda uygundur.

Anahtar kelimeler: Yanık sonrası boyun kontraktürü, havayolu yönetimi, I-jel

\section{CASE REPORT}

A 12-year-old male patient presented to our clinic for preoperative evaluation prior to scar revision surgery. The patient had extensive scarring from a burn, and kyphosis was caused by scarring of the inferior and temporomandibular joints to the anterior sternum and axillar region (Figures 1 and 2). On physical examination, no neck extension was observed and only partial flexion of the neck was possible. The oral opening was limited to $2 \mathrm{~cm}$ and the sternomental distance was $6.5 \mathrm{~cm}$. The thyromental distance was $3.5 \mathrm{~cm}$ and the Mallampati score was 4 . Therefore, intubation was considered difficult, and special preparations were made for it. After routine pre-oxygenation and propofol sedation, mask ventilation was successfully performed. Laryngeal structures were not visible due to the failure of orotracheal intubation. Supraglottic l-gel number 2.5 was used and ventilation was successfully achieved. The surgical plan necessitated tracheal intubation for safer ventilation.

\footnotetext{
${ }^{1}$ Dicle üniversitesi Tıp Fakültesi, Anesteziyoloji ve Reanimasyon AD, Diyarbakır

${ }^{2}$ Bezmiâlem Vakıf Üniversitesi Tıp Fakültesi Hastanesi, Anesteziyoloji ve Reanimasyon AD, İstanbul

${ }^{3}$ Dicle Üniversitesi Hastaneleri Plastik Rekonstrüktif ve Estetik Cerrahisi Hastalıkları AD, Diyarbakır
}

Correspondence: Taner Çiftci, Dicle üniversitesi Tıp Fakültesi, Anesteziyoloji ve Reanimasyon AD, Diyarbakır Email: taner.ciftci@hotmail.com 


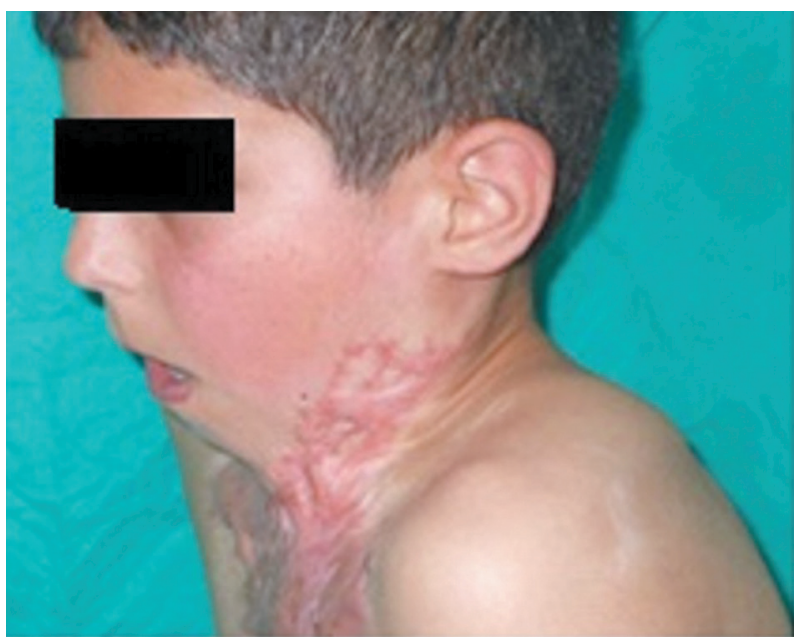

Figure 1. Side profile

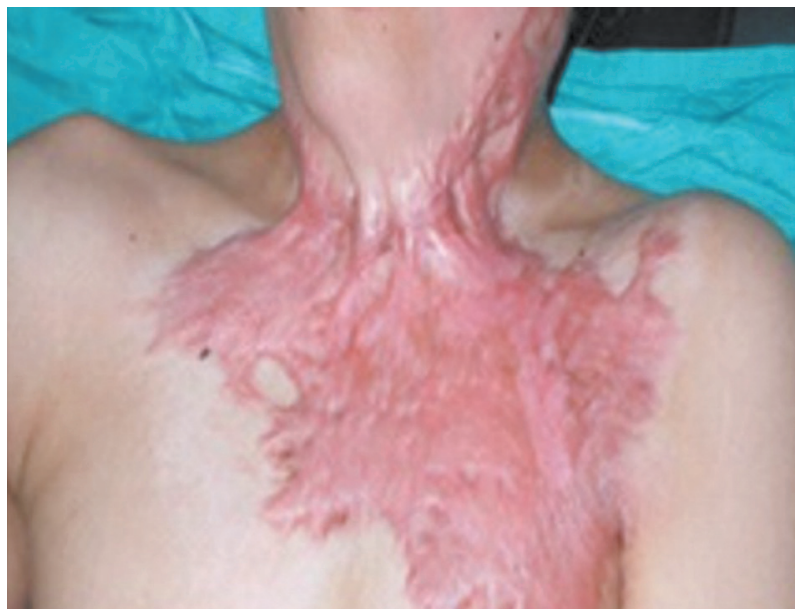

Figure 2. Front profile

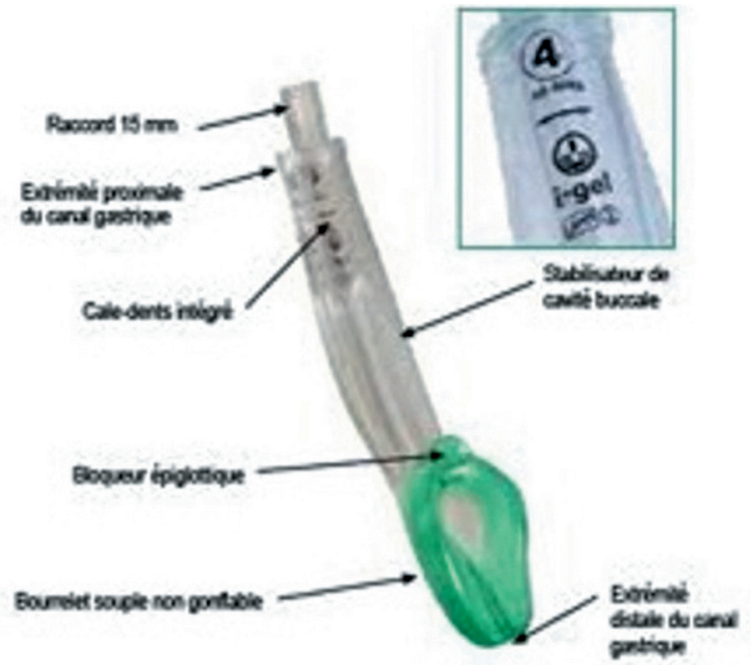

Figure 3. l-gel
After the scar tissue was released, better neck and oral mobility was observed. When a Cormack and Lehane score of 2 had been reached and the patient was intubated using a I.D: 5 orotracheal tube device [1]. During surgery, all vital signs and oxygen saturation level remained within normal limits. Surgery continued for $2 \mathrm{~h}$, and the patient was extubated after waking and spontaneous respiration occurred. The patient was hospitalized with an Aldrete score of 10 [2].

\section{DISCUSSION}

Anesthetic management of patients with limited airway access can be difficult. Limitations of the mandible, neck, and mouth and the absence of anatomic markers in the neck may create these difficulties [3]. Blind intubation, contracture release under local anesthesia, and orotracheal intubation may be facilitated by the use of an LMA (Laryngeal Mask Airway) Fast Track, or the help of a fiberoptic laryngoscope, extracorporeal membrane oxygenization, and the Igel. Tracheotomy application is another ventilation option when intubation is difficult [4].

Sheridan et al. utilized extracorporeal membrane oxygenation under anesthesia in an 18-month-old child during scar revision surgery of the head and neck. Orotracheal intubation became possible when relaxation of the neck was obtained [5]. This method is expensive and difficult to perform. In addition, bleeding and systemic inflammatory reactions may occur as a result of the necessity of using anticoagulants. Therefore, this technique was not used in the case reported here.

Awake fiberoptic bronchoscopy-assisted intubation is another option for easy and safe airway controls in patients with neck contracture [6]. This technique is usually preferred when orotracheal intubation, blind intubation, and supraglottic airway cannot be used [7]. In this case, the combination of LMA and I-gel was not possible. Due to lack of obstruction in the respiratory tract, we opted not to use this technique.

Releasing the neck contracture prior to intubation is another common choice, but problems may arise with the surgical plan, and possible complications include bronchospasm, risk of aspiration, and lack of emergency airway. Therefore, use of the supraglottic airway is more efficient and safer in patients with neck contracture. Tracheotomy is also used to achieve a safe airway in similar patients, but the lack of anatomic markers, malposition of 
the tracheal tissues, and details of the surgical plan precluded tracheotomy in this case. However, it remains the main method of airway access in emergency situations. The required equipment must be prepared when a significant intubation risk is present, as was the situation in the case reported here.

The popular I-gel technique was used for intubation of this patient. I-gel has a thermoplastic cuff with a soft pliable consistency, and no inflation is necessary (Fig.3). Compatibility with perilaryngeal tissues and stability after application are the advantages of this technique [8]. Using I-gel compared to LMA, Singh et al. in terms of ventilation time, airway leakage pressure, and fiberoptic view, They reported significantly greater success with I-gel than with LMA [9]. In the present case, supraglottic l-gel intubation was successfully performed in a patient with post-burn neck contracture after two unsuccessful attempts at orotracheal intubation.

In conclusion, various options should be available for intubation of patients with difficult airway access. Coordination with surgeons is essential during intubation. In the present case, the use of supraglottic l-gel was successful in intubation of a pediatric patient with post-burn neck contracture after two unsuccessful attempts at orotracheal intubation.

\section{REFERENCES}

1. Gray $\mathrm{H}$. Use of Cormack and Lehane grading with videolaryngoscopy. Anaesth Intensive Care 2013;41:123.
2. www.tard.org.tr/kilavuz/2.pdf

3. Park CD, Lee HK, Yim JY, Kang IH. Anesthetic management for a patient with severe mento-sternal contracture: difficult airway and scarce venous access -A case report Korean J Anesthesiol 2013;64:61-64.

4. American Society of Anesthesiologists Task Force on Management of the Difficult Airway. Practice guidelines for management of the difficult airway: an updated report by the American Society of Anesthesiologists Task Force on Management of the Difficult Airway. Anesthesiology 2003;98:1269-1277.

5. Sheridan RL, Ryan DP, Fuzaylov G, et al. Case records of the Massachusetts General Hospital. Case 5-2008. An 18-month-old girl with an advanced neck contracture after a burn. N Engl J Med. 2008;358:729-735. doi: 10.1056/NEJMcpc0708792.

6. Han TH, Teissler H, Han RJ, et al. Managing difficult airway in patients with post-burn mentosternal and circumoral scar contractures. Int J Burns Trauma 2012;2:80-85.

7. Bartolek D, Frick A. Huge Multinodular goiter with mid trachea obstruction: indication for fiberoptic intubation. Acta Clin Croat 2012;51:493-498.

8. Singh J, Yadav MK, Marahatta SB, Shrestha BL. Randomized crossover comparison of the laryngeal mask air way classic with i-gel laryngeal mask airway in the management of difficult airway in post burn neck contracture patients. Indian J Anaesth 2012;56:348-352.

9. Bamgbade OA, Macnab WR, Khalaf WM. Evaluation of the i-gel airway in 300 patients. Eur J Anaesthesiol 2008;25:865-866. 